\title{
How Mismanagement, Political Intrigues, Bad Monetary Policy and Corruption Doomed a Country
}

\author{
Sarkis Joseph Khoury \\ Unaffiliated- Retired Professor, School of Management, University of California, Riverside, USA
}

Email address:

Sjkhoury1@att.net

\section{To cite this article:}

Sarkis Joseph Khoury. How Mismanagement, Political Intrigues, Bad Monetary Policy and Corruption Doomed a Country. International Journal of Accounting, Finance and Risk Management. Vol. 6, No. 2, 2021, pp. 53-60. doi: 10.11648/j.ijafrm.20210602.13

Received: March 29, 2021; Accepted: April 13, 2021; Published: April 29, 2021

\begin{abstract}
This paper reviews the causes of the economic failure in Lebanon. It demonstrates that corruption, mismanagement of the public sector, political intrigue, and a misguided monetary policy have produced an economic calamity in the country. They turned Lebanon into one of the most indebted countries in the world and impoverished its citizenry. The Central Bank (BDL) pursued a policy focused on keeping the exchange rate at 1,500 LL/\$. To achieve this objective it offered the bankers very lucrative interest rates to insure they flow their dollar deposits to its coffers to stabilize the currency and to purchase dollar denominated country debt. With an underperforming economy, falling confidence in the governance of the country, and a massive drop in remittances from Lebanese immigrants living in various parts of the world, Lebanon defaulted on its international debt in 2020 despite numerous attempts through international organizations to prevent such an outcome. The paper argues that Lebanon has failed in stabilizing its currency and the economy and proposes dollarization as a permanent answer. It offers numerous ways for Lebanon to earn the necessary dollars for a well functioning economy.
\end{abstract}

Keywords: Corruption, Mismanagement, Failed Monetary Policy, Political Intrigue, Dollarization

\section{Introduction}

This paper focuses on the country of Lebanon and how the ruling class managed to impoverish the country through corruption accented by political intrigues, and the pursuit of a disastrous monetary policy.

Lebanon has all the ingredients for success that most countries dream about, yet it remains a divided, mismanaged, and underperforming country despite massive human and natural resources. The unyielding and corrupt political class in Lebanon forced massive emigration to various parts of the world. The end results were that the Lebanese immigrants were building societies and enterprises, leading research efforts in various disciplines, curing the sick, contributing to the political dialogue, lifting up educational levels, empowering the poor, and leading political movements in various parts of the world, but not successfully in their country, especially in the last decade.

The Lebanese national wealth has been squandered by the suffocating control of political oligarchs who are more committed to the accumulation of their wealth and their foreign patrons than the future of the country.
The Lebanese, since the days of the Phoenicians, immigrated to numerous countries, especially Latin America and the United States. Their interest in the events in Lebanon stayed strong. They are calling on the indigenous Lebanese to stop political bickering, start talking to instead of at each other, set an honorable and sustainable political/economic agenda, prosecute those that seek to undermine, if not disrupt the public will and the public good, and stop the theft of the public Treasury. They see a national emergency to save the country as 60 percent of the population is living below the poverty line, and as the debt burden became impossible to repay $[1,3,6,12,13]$.

The sad reality is that there are numerous, and compelling reasons for Lebanon to become a center for higher education, software development, car design, high fashion, architectural design and execution, money and bank management, and other fields. Genius and creativity are indeed exportable and have global value and the Lebanese have a large supply of them. However, instead of exporting the output of talent, they exported the talent itself and the country is poorer for it. 
Human capital in Lebanon is not the only national asset being squandered, Natural resources have been squandered as we. The neglect of the environment, the abuse of privileges acquired by the elite, the untapped energy reserves of Lebanon, and the overarching corruption are suffocating the country and creating a new level in the "misery index."

The energy resources of Lebanon are valued at one trillion dollars which is more than 100 times the national debt. If well managed, they could provide the funds needed to develop the most modern infrastructure in the world. Not a single barrel has been extracted, incredibly.

Lebanon can lead in producing clean energy that would eliminate much of the pollution in Lebanon [Cars converted to natural gas power is one easy possibility] and will cut the cost of electricity very substantially. The Israeli energy experience could be an example for energy development in Lebanon. Valuable lessons from Ireland and the way it handled the 2008-2009 financial crisis are also very relevant.

Ireland is a country with a similar size population, and a large number of citizens who migrated throughout the world, the United States especially. Twenty two US Presidents are of Irish descent. The 2008 financial crisis almost broke the back of Ireland. But working together, honestly and innovatively they solved vexing problems especially in the banking and technology sectors and managed to prosper.

Ireland's colleges are expanding, and its innovation district is thriving. Many banks are moving their headquarters from London to Dublin, Google hired 1,000 in Ireland for their CLOUD computing, Microsoft has 2,200 employees, Facebook has 4,000 employees, etc. Today Ireland is considered the most open economy after Singapore.

While the Irish focused on solving major political/ economic problems in the wake of the 2008-2009 crisis, Lebanon could not and would not. Too much division along political, regional, and religious lines prevented an effective resolution and produced instead the foundation of the current disaster. A flawed monetary policy compounded the problems.

We review in this paper the critical economic and monetary policies woven in a corrupt political system that brought Lebanon to the edge of the abyss. We also propose one radical solution to the current economic morass: dollarization.

\section{A Quick Review of Economic Events}

We begin with the macro-economic picture.

Lebanon has gone through substantial transformations since the end of the civil war in 1990. None was based on a rational, long term economic/political plan. Many of the changes were the results of politics and wars such as Israel's Operation Grapes of Wrath in April, 2006. The effects of such a war and the subsequent developments in Syria starting in 2011 had a major impact as seen in GDP growth and capital flows. GDP growth during the period 2011-2018 averaged $1.7 \%$. The glowing performance in economic growth or the 1990's with per capita GDP rising at about 7\% annually, "inflation falling to $5 \%$, and foreign exchange reserves rising to $\$ 6$ billion" were suddenly in the rear view mirror. The Lebanese pound held steady at the official rate of LL1500/US dollar. The preservation of this exchange rate became the consuming interest and preoccupation of the Central Bank (BDL), and the foundation of many problems.

The trigger for growth in the 1990's with GDP growth peaking at $8 \%$ in 1994 was a massive reconstruction program of \$20 billion starting in 1993. A slowdown in the reconstruction programs was experienced in the late 1990's as GDP growth slowed to $1 \%$ by 1999 .

The banking sector during that period was also doing well reflecting, once again, Lebanon's role as a "banking center" in the Middle East. By 2006 bank assets had reached \$ 75 billion and the small stock market was booming with total capitalization of $\$ 10.9$ billion (mostly from shares in Solidere (an indigenous real estate investment company) and from key commercial banks.

The international financial crisis of 2007-2010 caused havoc in the world financial markets, yet the Lebanese economy was prospering again with GDP growth of $8.5 \%$ in $2008,7 \%$ in 2009 , and $8.8 \%$ in 2010 .

During all these periods the national debt continued to rise. Lebanon became one of the most indebted countries in the world. That "distinction" never disappeared. The debt reached $\$ 90$ billion in 2019 or about 190 percent of GDP. This sum did not include money owed by the government to the Social Security Fund, to hospitals, and to private contractors. Even though Lebanon had a healthy primary balance in the budget on occasions, it was unable to generate enough funds to pay even the interest on the debt. Debt servicing plus interest thereupon amounted to one half of the government income. The rest went to public wages and corruption: Infrastructure projects be damned!

\section{The Central bank and Government Corruption}

Professor Jad Chaaban of the American University of Beirut wrote in a Facebook post that the debt crisis "is the creation of a failed and criminal political class that lied and robbed for more than 30 years".

The Lebanese economic and social demise started in 1992 with a clique of leading politicians taken direction and cooperating at all levels with the head of the central bank (BDL) They all knew what the desired (and realizable) and actual exchange rates for the Lebanese currency were. The commitment was to keep the exchange rate vis a vis the dollar at $1,200 \mathrm{LL} / \$$ initially. At this price the oligarchs bought a lot of dollars. The price of the currency fell to $3,000 \mathrm{LL} / \$$. They decided to sell their dollars at that price knowing full well that the Central Bank was committed to returning the currency to 1,200. At 1,200 They bought vast amounts of dollars with their large holdings of LL (Lebanese Lira). The scheme continued $\mathrm{xx}$ until the price was settled at 1,500.

In addition, the government decided to borrow massively in order to rebuild Lebanon from 15 years of civil war 
(1975-1990). The borrowing benefited largely the Oligarchs in numerous ways chief among the beneficiaries was $\mathrm{xx}$ Prime Minister Hariri who ended up owning a large chunk of swanky Beirut. The borrowing was initially in Lebanese pounds. The interest rates were shockingly over $40 \%$. Banks were required to keep 40 percent of their deposits in Lebanese government bonds yielding them a huge spread. Domestic interest rates normalized after a while. They later fell from outrageous rates when the government had minimal borrowing to much lower rate in the teens when the borrowing started in earnest domestically and internationally. The yield curve was inverted contrary to economic theory and reality: very high interest rates when the borrowing was minimal and then much lower interest rates when borrowing accelerated (Figure 1). The results of the massive borrowing made Lebanon one of the most indebted countries in the world. The borrowing did not stop the hemorrhaging in the government budget. Foreign debt largely denominated in US dollars became part of the debt portfolio (Table 1).

The results of the massive borrowing made Lebanon one of the most indebted countries in the world. The borrowing did not stop the hemorrhaging in the government budget. It accelerated. Lebanon was acting as if the debt will never have to be repaid. Indeed on March 7, 2020, the government announced what was totally anticipated: a default on all international debt owed by the government due on 9 March 2020.

These results were predictable:

"On March 9th Lebanon did not repay a \$1.2bn Eurobond, the first sovereign default in the country's history. Even during the darkest days of its civil war in the 1980s, the state met its obligations," declared the Prime Minister who added that "We will discontinue payment on all outstanding dollar denominated Eurobonds."

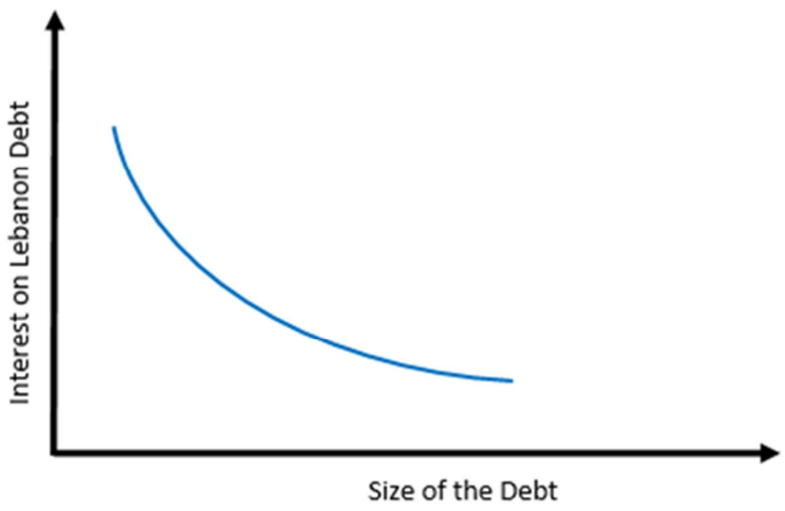

Figure 1. Relationship Between Interest and Debt Size.

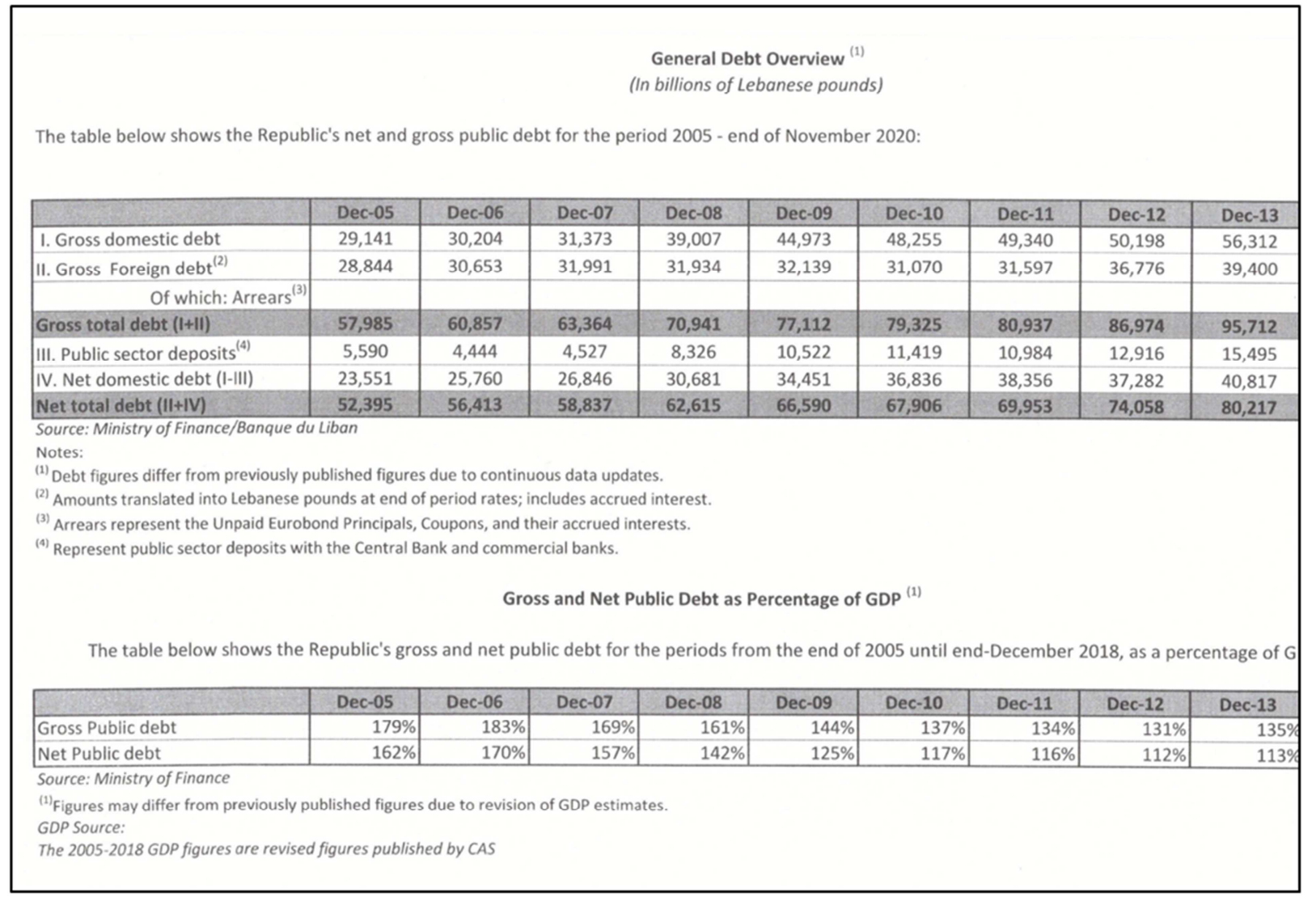

Figure 2. Level of Indebtedness - Domestic and International.

At the end of January 2020 The Lebanese Central Bank (BDL) had \$37 billion in gross foreign-currency reserves, but $\$ 52.5$ bn in liabilities, mostly owed to local banks. These banks had $55 \%$ of their assets tied up at BDL. Some put that percentage as high as $66 \%$ (they are at $40 \%$ in most countries). Banks had every incentive to keep money with the central 
bank and to buy government bonds as the returns were lucrative and substantially higher than any bank loan.

An 18\% loss on these holding of government securities would leave commercial banks insolvent and require "a recapitalization worth at least $25 \%$ of GDP". No solution was executed as of this writing.

And the earth shook! Insecurity was everywhere amidst the Corona virus. Debt cancellation and debt rollovers were not defensible. The man on the street understood that. The exchange rate started a free fall. Even his Falafel sandwich became very expensive. The demonstrations in the streets of Beirut went nowhere. They got rid of Hariri but kept all the problems.

The Lebanese Lira traded at as low as $200 \%$ below its official value. The problem continued and the IMF was trying to work out a solution in May of 2020. No solution was realized. By March 2021, the Lebanese Lira was trading at $11,000 / \$$ and then reached $(15,000 / \$)$.

The Lebanese government is politically inept and inefficient, unable to marshal enough resources to solve the problems without international assistance. The phantom of political intrigue and the contests between Saudi Arabia, Iran and Israel for influence in Lebanon, and the diminishing American and French interest in a permanent solution dominated the public dialogue.

Foreign Currency debt (mostly in Eurobond issues) amounted to almost $\$ 51$ billion dollars by December 2020 (Table 1) [o almost $\$ 51$ billion dollars by December 2020 (Table 1) $[14,15,3]$. All the previous international arrangements mostly through Paris Agreements failed to stem the tide.

The run to safety became obvious. Large depositors with the banks withdrew \$15 billion in 2019. Small depositors were restricted to withdrawing $\$ 200$ per month. The decision on the citizen money in a bank became that of the bank. The full deposit in the bank could not be withdrawn unless converted into Lebanese pounds at the old official rate, about ten percent of the black market rate. Strict limits on the withdrawal of dollar deposits were instituted. The maximum monthly withdrawal was $\$ 1,000$. The Oligarchs won again!

The effects were not symmetric across various communities The poor became poorer and organizations like Hizbollah, weary of supporting their social safety net, called on their external activities (arm sales, and all types of illegal activities) to stabilize their position. The voices of Christian leaders were muted.

With this background we now look at a sensible, but seemingly radical solution. But first a look at corruption Lebanese style.

\section{Some lessons in Corruption - The Lebanese Way}

The case we discuss here is symptomatic of the range of corrupt practices, that often defy credulity. The documented stories about the airplane leases by Middle East Airlines, the structured corruption at the Port of Beirut, and the stories about so called "waste management" are too numerous to treat here. We recommend a great book by Reinoud Leenders titled Spoils of Truce.

We focus on a manufactured crisis that is outside economic rationality. It was the first major crisis in the Lebanese banking sector that involved intrigues at the highest level, irresponsible banking practices, unwise actions by a new central bank, religious and nationality differences interfering in good governance, the use banking resources as one's own, political elites exercising their power when denied access for special consideration, regional political influences, and serious losses for small depositors.

I speak of the collapse of Intra Bank the largest bank in Lebanon at the time with $16 \%$ of banking deposits in Lebanon.

The story of Intra Bank revolved around a banker by the name of Yusuf Beidas, a Palestinian (mother and wife were both Lebanese) Greek Orthodox who set up financial operations in Lebanon n 1951.

From a money changer he became the principal owner of Intra Bank with 19,000 depositors and controlling interests in the Port of Beirut, Middle East Airlines, Lebanon's Casino, and major hotels. The bank quickly became multinational with offices in Arab Capitals, Brazil and Sierra Leone, London, Paris and New York.

In 1966 rumors (falsely) started circulating that the bank was insolvent: no longer able to meet its financial obligations to its lenders (depositors). By October 15 Intra Bank closed its doors. It did not declare bankruptcy, however.

Price Waterhouse was hired to audit the books. It concluded that the bank was indeed solvent, but clearly had a serious liquidity problem. Parenthetically, most Lebanese banks had a similar problem. They could not sustain a rush of withdrawals.

The Monetary Law of 1963 set up the central bank of Lebanon (Banque du Liban (BDL)) with the expectation that its regulatory powers will be light. Therefore, the ability of BDL to support Intra bank was limited but still substantial. BDL could have loaned the needed funds. It loaned Intra Bank only $\$ 15$ million dollars. The need was for at least $\$ 50$ million.

Most of the avenues available to US and European banks facing a liquidity crisis were not available to intra Bank despite its ownership of prime real estate in Lebanon, Paris, London, New York and other countries. Adding to the illiquidity of assets were two factors:

1- The development of the euro dollar market based in London promising secured bonds at higher interest rates. Arab depositors in Lebanon rushed to cash in decreasing the liquidity of Intra bank

2- Mr. Beidas seemed to have alienated the political class and the economic elite in Lebanon that was mostly Maronite and Sunni. They sat on the sideline watching the bank sink deeper. They could have bought more shares in the bank thereby infusing considerable liquidity. Unable to sell shares or substantial assets, the bank was restructured. Some of its assets were taken over by a new Bank: El Mashrek, and some of its creditors became shareholders in a new company: Intra Investment. The Lebanese government approved a budget to 
compensate small depositors. All directors were jailed. The Lebanese cabinet denied any bailout money, and did not permit the bank to reopen under the previous management and business model.

The tragedy of Intra Bank illustrated the caustic interaction between politics and finance and the corrupting involvement of the political/economic elite in the spoils of the system, especially when their "share" is not preserved o almost $\$ 51$ billion dollars by December 2020 (Table 1) [11, 13].

Another very illustrative case was that of Solidere, structured and largely owned by the then Prime Minister Hariri. Every advantage that could have been squeezed by Hariri and his co-investors from the government was indeed realized. It was a manifestation of political power over a massive real estate project with newly conceived interpretation of property rights. Our space here does not allow for the required discussion.

\section{The Role of the Dollar in the Lebanese Economy}

Since 1990 Lebanon has had a parallel currency system using the local currency (the lira) and the US dollar concurrently. The currencies were fully convertible almost anywhere in Lebanon at anytime. All merchants accepted them freely at the official rate $(1500 \mathrm{LL} / \$)$ and deposits in banks could be initiated using either currency with full convertibility on demand. Dollar deposits could be transferred overseas and used for any domestic purpose.

Pegging the LL to the US dollar required the Central Bank in charge of the peg to keep an ample supply of dollars in order to intervene when needed. The Central Bank also needed to finance the critical imports of the government to include fuel costing \$5 billion annually despite the untapped, massive gas and oil reserves Lebanon enjoys.

The twin towers of deficit spending: BOP deficits and budget deficits continued to accumulate and no real solution was successfully applied.

The introduction of the VAT tax and tax on interest income succeeded in trimming the budget deficits in 2003, 2004, 2005 and 2006. These reductions were consistent with the expectations of the Paris conferences. But the promoters of increased taxation did not consider its effects on economic activity and especially on capital inflows. They simply followed the French economic model and forgot about the wisdom of Ibn Khaldoun as reflected in the Laffer curve.

The traditional model when Lebanon got into a budgetary trouble relied on remittances: capital flows for investment purposes or simply for arbitraging interest rate differentials between those offered by Lebanese banks and their domestic bank, and on dollars from Lebanese exports (meager in terms of imports) to flow to Lebanese banks. They (the banks) in turn lend the money to the Central Bank (BDL) who will use the dollars to finance the government's international purchases of goods and services, and to provide for market intervention to stabilize the LL. If all fails, the dollars will be borrowed by issuing Eurobonds.

The best and simplest business in Lebanon for the elite became banking. The most valuable asset to bank owners was the BANKING LICENSE itself. Banks were receiving dollar inflows paying interest on them at a higher rate than was offered in many western economies without, superficially, any foreign exchange risk as the dollar peg was still holding. The bankers then deposited them with the central bank often at outrageously high interest rates while banks in Europe were receiving miniscule rates for their deposits with their central banks and often negative interest rates.

Then came a new reality as financial flows into the country began to fall drastically. The remaining flows could not cover the twin deficits and not even the interest thereon. The current account deficit was -14.7 billion in 2018, and -10.9 billion in 2019.

The continued borrowing to cover these deficits required additional measures. The only alternative, many thought, were the international organizations: The World Bank and the IMF. These organizations have been burdened by their involvement in Lebanon and they will extract major concessions were they to continue with yet another rescue package.

The international organizations were stymied by the inability of the Lebanese government to make the desired changes to limit waste and corruption. Good governance should rely on the enterprising people of Lebanon, stemming corruption, paying a lot of attention to tourism by cleaning up the country starting with clean water in Lebanon, and revamping the export sector.

\section{The Grand Solution}

The preceding discussion makes clear that The Lebanese government cannot live within its means and that the Central Bank (BDL) has not been able to successfully deal with the traditional functions of central banking. It became a terrible steward of the economy and indeed a co-conspirator.

Table 1. Excessive growth in the Money Supply (M1).

\begin{tabular}{llll}
\hline & M1 & M2 \\
\hline Money supply in the week ending & & \\
January 31, 2021 (Billion LBP) & $42,424.50$ & \\
Annualized weekly growth rate (\%) & & 17.51 & $69,303.20$ \\
(1) Weeks ending $2 / 28 / 2018$ to $6 / 30 / 2019$ & 392.41 & -22.33 \\
(2) Weeks ending $7 / 31 / 2019$ to $1 / 31 / 2021$ & 382.21 & -16.42 \\
(3) Weeks ending $5 / 31 / 2020$ to $1 / 31 / 2021$ & & 101.74 \\
\hline
\end{tabular}

Data collected and compiled by Dr. Poorna Pal 


\section{Lebanon's Money Supply M1 (Trillion LBP)}

(Source: http://www.take-profit.org)

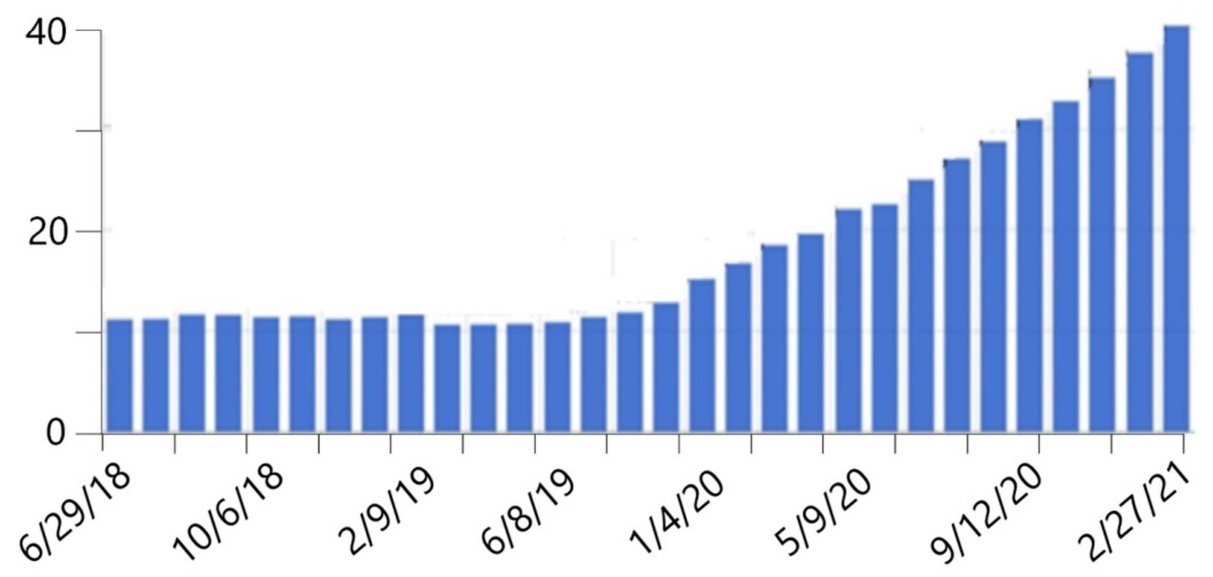

Figure 3. Lebanon Money Supply Data: Data source: Banque Du Liban (https://bdl.gov.lb).

BDL tried to manage the external debt through the years with mixed success. The out of control spending by the central government, the corruption, $\mathrm{xxx}$ the political intrigues and the unstable political structure left it invariably gasping for answers and reformulating strategies. All the international borrowing and restructuring with the IMF and the Paris Accords did not stop the hemorrhaging. The Central bank needing to provide liquidity to the government so public sector employees are paid and basic government duties performed (to include its required imports of oil, food, and flour) started printing money. Figure 3 shows massive issuance of domestic currency. MI rose by almost 400 percent during recent critical periods starting in July 2019. The results were very predictable making Lebanon a Hyper Inflation country and sinking the Lebanese pound to $15,000 \mathrm{LL} / \$$. Supporting the Lebanese pound at rates preceding the crisis became impossible.

\section{Our Proposal}

We are proposing a full dollarization of the Lebanese economy [2, 4, 5, 7-10], in order to stabilize the exchange rate permanently as a key foundation for economic growth. This is what this means:

1. The adoption of the US dollar as a full replacement of the Lebanese Lira. The US dollar will become the medium of exchange (as it already is to a very large degree), the unit of account and the store of value for all Lebanese transactions within and outside Lebanon.

2. BDL will no longer serve as lender of last resort.

3. The Lebanese economy will be integrated in terms of monetary policy with the United States. All Lebanese financial institutions will have to improve their standards and levels of efficiency.

4. The credibility of the US financial system in the world will be Lebanon's.

5. All foreign exchange rate risk relating to the Lebanese Lira will disappear. International investors coming to Lebanon will not worry about this risk. The remaining risk will be the volatility of the US dollar in the international markets. The world has effectively learned to cope with this volatility and there are many instruments such as forward, futures, and option contracts to hedge it.

6. All bank accounts and loans will be denominated in dollars. Every person in Lebanon will transact in dollars.

7. The risk premium Lebanon paid because of the uncertainty regarding the effectiveness of the peg will disappear. Lebanon will otherwise borrow at a lower rate internationally. Speculative attacks on the Lira would disappear much to the relief of the average Lebanese.

8. Lebanon will forfeit monetary autonomy- It will no longer have a unilateral control over it money supply. All dollars must be EARNED.

9. Transactions costs in the foreign exchange markets will be vastly eliminated.

10. The Lebanese people will have a currency that can be used anywhere in the world. The Lebanese pound had no value outside Lebanon.

11. The saving rate in Lebanon is likely to rise as the concern about currency crises disappears.

12. Substantial data on countries that have used dollarization in various forms (e.g. currency Board) do exist. The case of Argentina (Orthodox Currency Board) and especially Panama (dollarization) are very instructive and should encourage the consideration of this proposal.. Panama has many similarities with Lebanon as it is small, serves as a financial center, has a strong banking system, and its tourism is another major source of income. It also has a similar size population.

13. The risk of manipulating the currency system such as exists even in a currency peg or in a currency Board (a higher form of a peg) disappears.

Many issues that academicians have been talking o about such as seignorage (the benefit that a country derives from issuing its own currency that can be used by government to underwrite public expenditures) are really sideshows for a 
small country. The cost of such was estimated at $0.3 \%$ of GDP. To really understand seignorage look at the position the United States dollar occupies in the world economy. It allows the United States to print money to help control the effects of a Corona Virus, print money for the world to use, and run massive budget deficits without fearing an economic collapse. No small country can do all these things.

\section{Feasibility within Lebanon}

The Lebanese people are extremely familiar with the dollar. It is in their pockets, in their checking account and in their investment and retirement plans. Once overseas, they use the dollar as they did in Lebanon. Its acceptability anywhere is typically unchallenged. They say that the dollar is king because it is.

For a long period Lebanon had a parallel currency system that worked without a major problem. Americans entering Lebanon, and there are a lot of them in the summers, can use their own currency to buy anything in Lebanon, to invest in Lebanon, and to hold a bank account in Lebanon. Lebanon has a laissez faire system and enjoys considerable remittances from the United States and Latin America, especially. Inflows from Africa and the Middle East have also become significant.

US dollar deposits already account for about 70 percent of all deposits in Lebanon. Lebanese savers prefer dollars. The current crisis has taught them valuable lessons, as did the pre 1990 collapse.

The critical question in the implementation of a dollarization strategy is: how does Lebanon get all the dollars it needs to make its economy function?

Only a dramatic, comprehensive approach executed in all its elements simultaneously will rescue the Lebanese economy.

Here is what Lebanon must do to earn the needed US dollar to run a successful economy:

1. Refocus the reliance on traditional exports like olive oil and small manufacturing. Lebanon must rely going forward on exports with high intellectual capital. Its citizens have the training, education and the will for it if a free market is allowed to function without oppressive regulations. Expanding agricultural exports is possible but limited by the size of the country. A shift into high end agricultural exports such as Mango will indeed be wise. The Berytech Foundation in Beirut Lebanon recently launched the first Agri-food Innovation Cluster in Lebanon with the support of the government of the Netherlands" to serve as a platform for startups.

2. Lebanon has massive gas and considerable oil reserves. Their exploration and production must be the highest priority of the government. Schemes developed to freeze the government and the broader population from the benefits of oil and gas reserves must be trashed and their perpetrators exposed. At a minimum, Lebanon will save the $\$ 5$ billion oil import bill. Lebanon will become quickly a net exporter of energy. This alone can cover the deficit in the current accounts.

The additional benefits are environmental in Character. As in many countries, even in China, car engines have been converted to run on natural gas. This will create an industry in Lebanon and will reduce pollution that suffocates the country, especially during the summer months with wide-ranging impact on tourism. The health benefits are also enormous.

3. Remittances. Lebanon has a huge number of immigrants that have settled all over the world. Early in the 2000's they accounted at one time for as high as $24 \%$ of GDP. There are 20 million Lebanese residing in almost every country in the world. Their financial success has in some cases been legendary. Carlos Slim of Mexico, the richest man in the world for four years, is just one notable Lebanese success story. Lebanon must encourage cooperation programs between the various communities and create programs for their children to visit Lebanon and learn about their cultures and history. Some of that is already taking place. It must be expanded as the old guard is disappearing.

Every dollar that enters Lebanon, it must be noted, has multiplicative effects on the economy. It can be calculated using the spending multiplier:

\section{$\mathrm{M}=1 /(1-\mathrm{MPC})$}

Where MPC is the marginal propensity to consume.

4. Foreign Direct investment in Lebanon. Lebanon needs to clean up its image as an inefficient country with high level of corruption and commit to an infrastructure meeting international standards. The author knows of numerous cases where deals were cancelled because of the level of abuse and of the required size of the payoffs to officials and property owners. All basic services in Lebanon are expensive: electricity, water, telephones, cellular phone services. Add to the costs fees of all types.

Improvements can be made at all levels to demonstrate to the immigrant Lebanese population that they are indeed welcome and can thrive in Lebanon.

5. Tourism: Lebanon has traditionally gotten a fair share of international tourism. It was often been described as the Paris of The Middle East. Beautiful country side and beaches, elegant shops, dynamic culture, high end entertainment, and simply a fantastic cuisine covering most cultures have attracted millions of tourists. However, its beaches are now polluted, the streets are not as clean, the air is suffocating during traffic congestions, and its political divisions are too transparent and project poorly on what is considered a historically superior culture. With so many countries competing for tourist dollars, Lebanon is not winning. Some buildings in Lebanon are a reminder of a vicious civil war that unnerves every human being that reviews its history. Many of its landmarks are not well kept. Lebanon needs to clean up and realize its past success can be recreated and become a major source of foreign exchange.

\section{Conclusion}

This paper sought to show that while Lebanon is indeed in trouble, the situation is not hopeless. Much can be done to 
reduce its deficits, stabilize its currency and grow its economy. We laid out the path for these outcomes. It is quite important to signal a new age for Lebanon through Legal reforms that will put some of the thieves of the national wealth behind bars. Every visitor to Lebanon is usually weary of being scammed. Lebanon cannot afford this reputation. It must stop. The transition into a dollarized economy will take a little time, but will critically remove the Central Bank from the exchange manipulation business. The IMF should assist Lebanon in that short journey especially with the conversion of the $\$ 8.8$ billion Lebanese pounds now in circulation to dollars at an acceptable exchange rate. Also the bankers in Lebanon must also show they are willing to compromise and to sacrifice for the national good. Their holdings of domestic debt in Lira should be cancelled. The bankers in Lebanon have already earned their principal investment many times over given the outrageous interest rates they received from BDL. Prayers will also help.

The Central Bank, BDL, must clean up its balance sheet and insist on a fiscal reform that will once and for all force the government to live within its means. This starts with the reduction of the massive public payroll that is politically charged. The rejuvenated private sector will be able to absorb the laid-off government employees.

\section{References}

[1] Carnegie Middle East Center, Lebanon's Economic Crisis: A ten Point Action Plan for Avoiding a Lost Decade, 2020.

[2] Cohen Benjamin, Dollarization: Pros and Cons, Working paper, UC Santa Barbara.

[3] Financial Times, many articles especially that of Chloe Cornish.

[4] Hanke Steve- we used several of his publications as references because: His international appointments also include state counselor to both the Republic of Lithuania in 1994-96 and the Republic of Montenegro in 1999-2003. He advised the presidents of Bulgaria (1997-2002), Venezuela (1995-96), and Indonesia (1998). He played an important role in establishing new currency regimes in Argentina, Estonia, Bulgaria, Bosnia-Herzegovina, Ecuador, Lithuania, and Montenegro. Hanke has also held senior appointments in the governments of many other countries, including Albania, Kazakhstan, the United Arab Emirates, and Yugoslavia.

[5] International Monetary Fund, Full Dollarization: The Pros and the Cons, 2000.

[6] Jakub Jaycay, Intra Bank, Lessons from Lebanon's First Banking Collapse, 2020.

[7] Koury S Institutional Competition as an Alternative Mechanism for Harmonization in Monetary and Banking Union, with Clas Wihlborg, Forum for EU Debate, Stockholm, 2014.

[8] Khoury S,-Trust in the Euro and the Banking Union after Financial and Sovereign Crises, with Clas Wihlborg., book chapter by Palgrave Macmillan, 2017.

[9] Khoury S Negative Interest Rates, with Poorna Pal, Journal of Risk and Financial Management, 2020.

[10] Moubayed and Zouein: Finding a Way Out of Lebanon's Crisis, 2020.

[11] Norton Augustus Richard, The Role Of Hezbollah in Lebanese Domestic Politics, The International Spectator, Italian Journal of International Affairs, 2007.

[12] Saidi Nasser, Lebanon's Economy: Staring at the Abyss, 2020

[13] Salloukh Bassel, Taif and the Lebanese State: The Political Economy of a very Sectarian Public Sector, Routledge, 2019 S\&P: Lebanon's Banking Sector Shows 'Similarities' to Greece Before, 2019.

[14] Lebanon Ministry of Finance Statistical Data

[15] Financial Times - Various Special Reports on Lebanon. 